FACTA UNIVERSITATIS

Series: Teaching, Learning and Teacher Education Vol. 1, № 2, 2017, pp. 101 - 112

https://doi.org/10.22190/FUTLTE1702101C

Original research paper

\title{
CONFLICTS IN ELEMENTARY SCHOOLS THROUGH STUDENTS' PERCEPTION
}

UDC 316.624-057.874

\section{Marina Ćirić1, Mirjana Pavićević², Nataša Ćirićc}

${ }^{1}$ Faculty of Philosophy, University of Niš, Serbia

${ }^{2}$ Elementary School "Nadežda Petrović", Niš, Serbia

${ }^{3}$ Elementary School “Čegar”, Niš, Serbia

\begin{abstract}
Conflicts are present in every aspect of the child's process of growing up-in school, family, with friends, and sports clubs. Nowadays, kids are often surrounded by peer violence which manifests in verbal, mental, and physical form. Attempts to solve such conflicts often result in making things even worse. The root cause of those issues is a different perspective on the problems at hand. The main goal of this research is to understand students' perspective on conflicts they come across at school. We used descriptive statistics methods (frequency) and $\chi^{2}$ test for measuring the significance of differences among crossed variable segments. Results of this research showed that the number of conflicts increases with age, meaning that there are more conflicts in higher grades. When it comes to solving these conflicts, students are prone to turning to teachers and professional associates at school, regardless of the fact that their parents show the desire to engage in solving peer conflicts.
\end{abstract}

Key words: social conflict, students' perception, violent behavior, school environment, upbringing

\section{INTRODUCTION}

The school environment should primarily provide safety and encourage child's development. One of the main tasks of teachers and professional associates should be to ensure a safe and stimulating environment for development and learning. That's why experts that are a part of the schooling system bear a great responsibility in regards to constructive conflict-solving by increasing sensitization and developing a positive climate in schools. The role of school's climate in conflict-solving and preventing violence among students comes from the social influence as a context which has a

Received September 12, 2017/Accepted October 5, 2017

Corresponding author: Marina Dragan Ćirić

Faculty of Philosophy, University of Niš, Ćirila i Metodija 2, 18000 Niš, Serbia

Phone: +38118 514-312•E-mail: marina.ciric@ filfak.ni.ac.rs 
potential of ensuring the assumptions that a proper development of cognitive and socials skills influences the decrease of child's tendency to use force for achieving their social goals.

In day-to-day professional educational work, especially lately, social conflicts often occur. Conflict is a situation where two or more people or groups want to carry out their goal, interest or need. However, in order to achieve their personal goal, they think solely of themselves, they store their energy to enforce it, and they see the other side that is involved as an obstacle or a threat (Zečević, 2010). The narrower term, social conflicts defined as a situation of conflictive events, tendencies, behaviors, and emotions with at least two opposing sides, where each side perceives the other either as a threat or an obstacle towards accomplishing a certain goal. It's based on the inconsistency of perception, grades, attitude, desires, and values i.e. the inconsistency of opposing sides' goals where only one is achievable. So, in order to achieve it the energy is being engaged which results in an incompatible action within the group (Mirolović \& Vlah, 2004). Conflict can also arise when two sides don't have interdependent goals, yet one side strives to interfere with other side's target. In every type of relationships, interpersonal and others, certain bothersome behaviors might also occur. However, these patterns usually slide by without creating a major conflict (Jevtić, 2015).

Within a social conflict's structure, there are certain interrelated elements. Those are a) conflict situation b) conflict 1 behavior and c) conflict attitude and perception (Vlah, 2010). The conflict situation can be any given situation where two or more opposing sides perceive a mutual misbalance. As such, it is present in children as well as adults, in everyday play. One of its characteristics are goals which are observed by both sides. However, the manner of perception implies the fact that people have different views of reality. A huge number of social conflicts is a result of such differences.

Based on the effects which arise during conflicts, we differ: (1) Functional - conflicts which lead to constructive changes in relationships among individuals/groups, they increase efficiency; (2) Dysfunctional - conflicts which lead to stagnancy, deteriorating relationships, violence. When a conflict is dysfunctional it leads to negative outcomes, such as: tension, which interferes with the group dynamics, endangers personal and group interests, which leads to a lack of motivation and support; negative emotional expression when the whole group is absorbed in the conflict that it can cause violence; undermining of the group's unity, when members have to pick sides, differences become the main focus, the morale drops, and priority reorganization occurs; endangering the possibility of a positive change, which draws huge amounts of energy (Zečević, 2010, 15).

Children spend a lot of time at school, so that is the main common ground of conflict appearances. Risk factors at school are referring to an academic failure and unjustified absences, which are followed by mistrust towards teachers and the school, in general. The negative characteristics of the school include an unfavorable psychosocial climate, inconsistent rules, and a high level of delinquency among students (Johnson \& Johnson, 1996). It is very important that professionals working in schools respond in a timely manner when they notice that certain hostility develops among students. Also, this knowledge should be shared by the students themselves, in order to recognize in which phase of the conflict they are currently in and react promptly on their own or ask for help from the elderly and solve the problem. Accordingly, Jones (2004) lists four basic goals that are sought within the International Conflict Resolution Education Programs: (1) create a safe learning environment; (2) achieve a constructively oriented learning environment; (3) to promote the social and emotional development of students; (4) to encourage constructive conflict resolution at school. In this way, the overall climate and culture of the institution 
are directed towards the prevention and suppression of conflicts among participants in the educational process.

Each conflict has the potential to be functional or not primarily depending on the attitudes and reactions of participants in it. It is important to keep in mind that in each conflict situation we have the ability to choose which way we will start. It is important to know that the type of conflict and the type of relationship in which the conflict occurs or the significance of the conflict and the other side of the conflict determines the choice of strategy that will be applied in resolving the conflict (Petrović \& Vučetić, 2012). It should be noted that not all conflicts are harmful. "It is justified to distinguish harmful from beneficial and destructive from constructive conflicts" (Rot, 2010, 289). The central problem of our research relates to conflicts among students. Our goal was to find out the pupils' opinion on conflicts at school and to point to the possibility of a functional conflict resolution.

\section{The Role of SCHOOL In PREVENTION OF CONFLict/ViolenCE BETWEEN STUDENTS}

Social critics of the 20th century consider that school closeness hinders socialization, and as a result, the inability of children to adopt behavior that would contribute to their development occurs. The absence of relevant values results in the onset of violence in the adolescent period (Zdravković, 2010). Conflicts in the school context are organizational since interpersonal relationships in school have the characteristics of institutional relationships (Deutsch, Coleman \& Marcus, 2006). From the stated specificity of the mutual roles and the hierarchy of relations, it is necessary to point out the measures of suppression and prevention of conflicts in schools in Serbia. Based on the Special Protocol for the Protection of Children and Students from Violence (2007), abuse and neglect in educational institutions, each school is obliged to define in its annual work plan the Plan and program for protecting students from violence, and to establish a Student Protection Team. The existence of this Program provides planning and implementation of preventive activities, an establishment of clear roles and procedures in violent situations. Violence prevention programs should enable the establishment of positive and supportive relationships between the child, adults, and peers, to free children to talk about their attitudes and feelings, to develop their own interests and competencies. It is necessary to direct the intervention to the whole environment. In order to prepare a high quality and functional program for the protection of children against violence, it is necessary to analyze the state of security in the school, with special attention being paid to the specific manifestations of violence. Based on this data, we plan preventive programs and monitor their effectiveness. In order to analyze the state of security, it is necessary to obtain as objective data as possible, for which the opinion of employees, pupils, and parents is very important, especially students who are the most exposed to the violence or are the ones who enforce it. The analysis of the state of security in the school should be linked to the process of self-evaluation, work evaluation, and development planning, where the role of the pedagogue is very significant.

Based on the analysis of the key area, the Program for the Protection of Children against Violence is planned, which includes: (1) Preventive measures - what measures can schools take to prevent and reduce violence and how the institution monitors the effects of prevention; (2) Intervention measures - what measures the schools take when violence occurs, which procedures are used, and how roles and responsibilities are shared. 


\section{Precautionary measures}

The school must not only react to any conflict or violence that is happening there, but it also has a duty to take preventive activities in order to completely avoid conflicts. Prevention of violence in educational institutions is a set of measures and activities aimed at creating a safe and positive environment, fostering an atmosphere of cooperation, respect and constructive communication, in which there will be no violence or will be as little as possible (Handbook for the implementation of a special protocol for child and student protection from violence, abuse, and neglect in educational institutions, 2009). In this sense, the best way to achieve a positive, stimulating atmosphere in the school is to send messages of appreciation, trust, and support, as well as messages of interest and of security" (Jovanović, 2009, 275).

The basis of preventive measures is the development of social and communication skills in children and students achieved through the educational work of the institution. These skills enable a better understanding of oneself and others, building positive relationships with others, accepting responsibility for expressed feelings, and managing conflicts.

The role of teaching staff in identifying and preventing violence is very important, and it is necessary to provide continuous professional development in educational institutions on the topic of violence and prevention.

Students need to be provided with a diverse offer of extra-curricular activities that should be in line with the needs and interests of children (interesting, entertaining, and attractive), focused on constructive and creative development, to contribute to the quality use of leisure time outside the institution. It is necessary to plan extracurricular activities involving as many children as possible from vulnerable and risk groups.

In order for the violence prevention to be effective, it is necessary to define clear rules of behavior. The goal of clearly formulated rules of conduct is to inform pupils about which rules exist, and by doing that, their importance rises. The goal of making rules of conduct is that those group rules become norms, meaning that they are mostly accepted and respected. Rejection of aggression between students should also become a norm, with increasing visibility and it should be binding. The rules of conduct should be clearly written and hung in a visible place in the school hall so that the children will have the opportunity to read them daily and remind themselves of the norms.

Active participation of students in determining the rules of conduct and their consistent application will help with prevention, as well as early identification of violence in schools. In order to achieve the real effects of preventive activities, it is essential that students are actively involved in all stages of prevention, from planning to realization and evaluation of results. Some forms of work with students that have a motivational effect and endorse active inclusion at all ages are: (1) workshops, discussion groups, tribunes; (2) visiting and organizing theater performances, recitals, exhibitions; (3) competitions and works of art (drawings, posters, comics, photographs, cartoons); (4) sports, cultural and other meetings (Handbook for Implementation of a Special Protocol for the Protection of Children and Students against Violence, Abuse and Neglect in Educational Institutions, 2009, 24). In addition to cooperation with students, it is necessary to achieve cooperation with parents and the local community.

\section{Intervention measures}

An important preventive measure against a renewed conflict that can turn into violence is a successful intervention. Interventional measures include the following: educating adults and 
children to recognize violence and act in an appropriate manner. Successful intervention involves teamwork and the establishment of clear rules and procedures in front of the whole team. The intervention includes the following steps (Handbook for Implementation of a Special Protocol for the Protection of Children and Students against Violence, Abuse, and Neglect in Educational Institutions, 2009):

1. Detection and the awareness of violence is the first step in protecting students from violence. In some cases, the signs of violence are obvious, while in other situations it is very difficult to detect the problem, and therefore the role of professionals and the person who enjoys the trust of the child is very important. It is particularly difficult to find out if the child suffers emotional or social violence. Sometimes the sole behavior of a child indicates the existence of a problem, and it should be borne in mind that children react differently: they are pulling back and become irritable, aggressive, hypersensitive, and so on.

2. Stopping violence is obligatory for all who have any knowledge or suspicion that violence is being enforced. Employees are obliged to stop violence and/or notify the authorities at the institution. It is recommended that possible ways of reacting to different situations are agreed upon in the institution in advance. In this way, it would be a precautionary response to the stigma and, perhaps, inadequate response. It would also prevent negative consequences.

3. Responding to the situation implies ensuring safety for the child/pupil and talking with participants and observers. In this process, it is important that the institution operates in a synchronized manner so that the conversation with students about the same situation is not done repeatedly by different employees. Also, an effective response and the flow of relevant information must be ensured within the internal protection network.

4. After stopping the violence and calming the participants, an employee who has reacted directly or has knowledge of violence initiates consultation within the institution to assess the risk and elaborate a protection plan for all participants. At this stage, the Team assesses the degree of risk and decides how to address the case, whether it will independently resolve or involve other relevant institutions. Consultations with a psychologist are necessary in case they are not a member of the Team.

5. After stopping the violence and finished consultations with relevant experts and/or institutions, the agreed upon activities and measures of protection are implemented. In this context, it is important that individual obligations and responsibilities are specified and implemented consistently. Monitoring the effects of the measures taken in order to verify the effectiveness of the protective measures that had been undertaken, the deputy team plans to monitor and evaluate the procedures applied in relation to all the participants of the violent incident that had occurred. The monitoring result should be a continuous development and improvement of preventive activities and various intervention models. On the basis of the analysis, measures and activities for improving the work of all participants in this area are defined.

Within the framework of protection measures, activities will also be planned to ensure the reintegration of all participants of the violent events into the institutional community and ensure a safe and quality life and work in the school. The reintegration plan will depend on a few factors such as: the form and intensity of the violent act, the consequences of violence per individual and the collective, the number of participants, etc. Measures to determine the consequences of violent and prosaically behavior are so-called reward and discipline 
measures. The aim of these measures is to reduce aggressive behavior through rewards and punishments and to increase acceptable behavior which is incompatible with aggression. This improves the working conditions that lead to a better overall school climate.

\section{METHOD}

The central problem of this research relates to conflicts among pupils in elementary schools. The aim of the research is to find out the pupils' opinion on conflicts at school. The tasks derived from the research objective are: 1) to examine statistically significant differences in student attitudes about the incidence of conflict in school; 2) examine statistically significant differences in students' attitudes on providing assistance from adults in conflict resolution.

In accordance with the tasks set forth, the following hypotheses are given: 1) there are statistically significant differences in perceptions of pupils about the incidence of conflict in school; 2) there are statistically significant differences in perceptions of students on providing assistance from adults in conflict resolution. The survey included a sample of 81 pupils at Elementary School "Čegar" in Nis. The sample is random and the sample structure is shown in Table 1.

Table 1 the sample structure

\begin{tabular}{lcc}
\hline Grade & Frequency & Percentage (\%) \\
\hline Sixth & 24 & 29,6 \\
Seventh & 26 & 32,1 \\
Eight & 31 & 38,3 \\
\hline GPA & & \\
\hline Good & 7 & 8,6 \\
Very good & 27 & 33,3 \\
Excellent & 47 & 58,0 \\
\hline $\mathrm{N}$ & 81 & 100,0 \\
\hline
\end{tabular}

The research used the following variables: class and school success of students as independent variables and pupils' attitude about conflicts in elementary school as a dependent variable. Data processing was performed using the SPSS Windows version 21 software package. The statistical processing used the descriptive statistic (frequency) method and the $\chi^{2}$ test to measure the significance of the differences between the segments of the crossed variables. The research was carried out in the first semester of the school year 2016/2017.

\section{RESULTS OF RESEARCH AND DISCUSSION}

The results of the research were grouped in accordance with the tasks and research hypotheses. The first task was related to the frequency of conflicts among pupils at the school. By comparing students' perceptions within each of the classes in Table 2, we found that most of the students in the seventh grade survey believe that the conflict is frequent $(50 \%)$ in relation to the students of the sixth $(50 \%)$ and the eighth $(41,9 \%)$ grade who emphasize that conflicts happen occasionally. Respondents of all grades agree that conflicts 
are repeated mainly among the same students. A large number of students in the eighth grade, $61.3 \%$, pointed out that they themselves were participants in conflicts among peers, compared to students attending the sixth $(45,8 \%)$ and seventh $(38,5 \%)$ grade.

Table 2 Frequency of conflicts among students in schools in relation to the grade they're attending

\begin{tabular}{|c|c|c|c|c|c|c|c|}
\hline \multirow{3}{*}{ Conflicts } & \multicolumn{7}{|c|}{ Grade } \\
\hline & \multirow{2}{*}{ Students' perception } & \multicolumn{2}{|c|}{ Sixth } & \multicolumn{2}{|c|}{ Seventh } & \multicolumn{2}{|c|}{ Eight } \\
\hline & & $\mathrm{f}$ & $\%$ & $\mathrm{f}$ & $\%$ & $\mathrm{f}$ & $\%$ \\
\hline \multirow{3}{*}{$\begin{array}{l}\text { Conflicts among } \\
\text { students occur }\end{array}$} & Frequently & 2 & $8,3 \%$ & 13 & $50,0 \%$ & 7 & $22,6 \%$ \\
\hline & Occasionally & 12 & $50,0 \%$ & 8 & $30,8 \%$ & 13 & $41,9 \%$ \\
\hline & Rarely & 10 & $41,7 \%$ & 5 & $19,2 \%$ & 11 & $35,5 \%$ \\
\hline \multirow{4}{*}{ Conflicts reoccur } & $\begin{array}{l}\text { Usually among the same } \\
\text { students }\end{array}$ & 11 & $45,8 \%$ & 14 & $53,8 \%$ & 18 & $58,1 \%$ \\
\hline & Among different students & 10 & $41,7 \%$ & 7 & $26,9 \%$ & 4 & $12,9 \%$ \\
\hline & Between groups of students & 1 & $4,2 \%$ & 4 & $15,4 \%$ & 2 & $6,5 \%$ \\
\hline & Don't reoccur & 2 & $8,3 \%$ & 1 & $3,8 \%$ & 7 & $22,6 \%$ \\
\hline \multirow{2}{*}{$\begin{array}{l}\text { Conflict } \\
\text { participation }\end{array}$} & Yes & 11 & $45,8 \%$ & 10 & $38,5 \%$ & 19 & $61,3 \%$ \\
\hline & No & 13 & $54,2 \%$ & 16 & $61,5 \%$ & 12 & $38,7 \%$ \\
\hline
\end{tabular}

Based on the calculated $\chi^{2}$ value of 11,652 with the corresponding degree of freedom $\mathrm{DF}=4$ and the significance level $\mathrm{p}=0,02$, it was found that there is a statistically significant difference between the students' attitudes about the incidence of conflicts in relation to the grade they are attending. Based on the students' opinions, it can be concluded that conflicts among students are present, but that their frequency differs in relation to the grade they're attending. The largest number of conflict participants is in the eighth grade. What's interesting is the students' perception about the incidence of conflict in school. Despite the fact that most of the eighth-grade students had participated in conflicts at some point, only $22 \%$ of them believe that conflicts are frequent, as opposed to students of the seventh grade $(50 \%)$ who were involved in conflicts to a much lesser degree but still thought conflicts are common.

In the same Table, it is shown that conflicts occur mainly among the same students, which makes it easier to resolve conflicts because if teachers and the expert service have the knowledge that certain students initiate conflicts, they can organize enhanced education to solve the problem. At the same time, we can see that the number of students in conflicts is declining with age. The biggest number of different students that are in conflicts is in the sixth grade $(41,7 \%)$, in the seventh $26,9 \%$, and only $12,9 \%$ in the eighth grade. It can be clearly seen that the number of students in conflicts decreases with age, but the number of students being involved in conflicts increases, which proves that certain individuals initiate conflicts or participate in them.

Academic indicators relate to low inclusion in teaching and non-fulfillment of school obligations, absence from teaching and experiencing school as an undesirable place (Suzić, 2010). The analysis of students' attitudes, from the aspect of academic excellence in Table 3 shows that students who achieve good results at school consider that conflicts are frequent, $71,4 \%, 57,1 \%$ of which is between the same students, and that a large percentage of them, 85, and 7\% was involved in conflicts at school at some point. The largest number of respondents, with very good overall grades, declared that they think 
that peer conflicts are rare, $44,4 \%$, and that conflicts were repeated among different students, $33.3 \%$. Still, although they believe that the conflict rarely arises, a large number of them $(70,4 \%)$ answered our question whether he was a participant in the conflicts affirmatively. Students with excellent achievement consider that conflicts are occasional, $51.1 \%$ and that the ones involved are mostly the same students $55,3 \%$. The greatest number of excellent students, $68,1 \%$ have never been a participant of conflicts. It is important to emphasize the fact that the understanding of the concept of conflict is different for different students, despite the fact that, before the start of the research, the participants were explained what is considered to be a conflict.

Table 3 Frequency of conflicts between students in relation to their academic achievement

\begin{tabular}{|c|c|c|c|c|c|c|c|}
\hline \multirow{3}{*}{ Conflicts } & \multirow{3}{*}{ Students' perception } & \multicolumn{6}{|c|}{ Academic achievement } \\
\hline & & \multicolumn{2}{|c|}{ Good } & \multicolumn{2}{|c|}{ Very good } & \multicolumn{2}{|c|}{ Excellent } \\
\hline & & $\mathrm{f}$ & $\%$ & $\mathrm{f}$ & $\%$ & $\mathrm{f}$ & $\%$ \\
\hline \multirow{3}{*}{$\begin{array}{l}\text { Conflicts } \\
\text { among } \\
\text { students occur } \\
\end{array}$} & Frequently & 5 & $71,4 \%$ & 6 & $22,2 \%$ & 11 & $23,4 \%$ \\
\hline & Occasionally & 0 & $0,0 \%$ & 9 & $33,3 \%$ & 24 & $51,1 \%$ \\
\hline & Rarely & 2 & $28,6 \%$ & 12 & $44,4 \%$ & 12 & $25,5 \%$ \\
\hline \multirow{4}{*}{$\begin{array}{l}\text { Conflicts } \\
\text { reoccur }\end{array}$} & $\begin{array}{l}\text { Usually among the same } \\
\text { students }\end{array}$ & 4 & $57,1 \%$ & 13 & $48,1 \%$ & 26 & $55,3 \%$ \\
\hline & Among different students & 2 & $28,6 \%$ & 9 & $33,3 \%$ & 10 & $21,3 \%$ \\
\hline & Between groups of students & 1 & $14,3 \%$ & 1 & $3,7 \%$ & 5 & $10,6 \%$ \\
\hline & Don't reoccur & 0 & $0,0 \%$ & 4 & $14,8 \%$ & 6 & $12,8 \%$ \\
\hline \multirow{2}{*}{$\begin{array}{l}\text { Conflict } \\
\text { participation }\end{array}$} & Yes & 6 & $85,7 \%$ & 19 & $70,4 \%$ & 15 & $31,9 \%$ \\
\hline & No & 1 & $14,3 \%$ & 8 & $29,6 \%$ & 32 & $68,1 \%$ \\
\hline
\end{tabular}

Based on the results, we can conclude that the frequency of the conflict in relation to school success varies. In support of this, we have the $\chi^{2}$ value of 11,923 at the degree of freedom $\mathrm{df}=4$ where the significance level is $\mathrm{p}=0,018$. This is the first hypothesis that confirms a statistically significant difference in students' attitudes about the frequency of school-related conflicts.

From Table 4, which refers to the assistance providing from adults in conflict resolution in relation to the grade the student is attending, we can notice that the students of the sixth $(62,5 \%)$ and the eighth $(45,2 \%)$ grade usually include class supervisors in conflict resolution, while in the seventh grade, the school's expert service is involved, $34,6 \%$.

If we analyze the structure in more detailed manner, we will notice that pupils more often turn to teachers and professional associates than parents. This phenomenon is developmentally justified and expected, given the developmental need to end the symbiotic relationship with parents, with the aim of forming an independent and later mature and independent personality (Tomonjić, Blagojević-Radovanović \& Pavlović, 2010). Regardless of the fact that pupils prefer to turn to teachers for help, they believe that parents show willingness to engage in solving peer conflicts.

By testing the differences between students' attitudes, we obtained a statistically significant difference of $\chi^{2}$ which amounts to 22,026 for degrees of freedom $\mathrm{df}=8$ where the level of significance is $p=0,005$. 
Table 4 Adults' assistance in conflict resolution in relation to the grade the student is attending

\begin{tabular}{|c|c|c|c|c|c|c|}
\hline \multirow{3}{*}{ Conflicts } & \multicolumn{6}{|c|}{ Grade } \\
\hline & \multirow{2}{*}{ Students' perception } & \multicolumn{2}{|c|}{ Sixth } & Seventh & \multicolumn{2}{|c|}{ Eight } \\
\hline & & $\mathrm{f}$ & $\%$ & f $\%$ & $\mathrm{f}$ & $\%$ \\
\hline \multirow{4}{*}{$\begin{array}{l}\text { People who are } \\
\text { involved in } \\
\text { conflict resolution }\end{array}$} & Other students & 3 & $12,5 \%$ & $\begin{array}{ll}519,2 \% \\
\end{array}$ & 5 & $16,1 \%$ \\
\hline & Class supervi & 15 & $62,5 \%$ & $830,8 \%$ & 14 & $45,2 \%$ \\
\hline & Teachers & 2 & $8,3 \%$ & $415,4 \%$ & 0 & $0,0 \%$ \\
\hline & Psychologist, pedagogue & 4 & $16,7 \%$ & $934,6 \%$ & 12 & $38,7 \%$ \\
\hline \multirow{5}{*}{$\begin{array}{l}\text { People whom they } \\
\text { turn to for help }\end{array}$} & Friends & 3 & $12,5 \%$ & $0 \quad 0,0 \%$ & 6 & $19,4 \%$ \\
\hline & Teachers & 18 & $75,0 \%$ & $934,6 \%$ & 9 & $29,0 \%$ \\
\hline & Psychologist, pedagogue & 1 & $4,2 \%$ & $830,8 \%$ & 6 & $19,4 \%$ \\
\hline & Parents & 2 & $8,3 \%$ & $415,4 \%$ & 4 & $12,9 \%$ \\
\hline & No-one & 0 & $0,0 \%$ & $519,2 \%$ & 6 & $19,4 \%$ \\
\hline \multirow{3}{*}{$\begin{array}{l}\text { Parents' } \\
\text { willingness to } \\
\text { assist }\end{array}$} & Fully wil & 24 & $100,0 \%$ & $2492,3 \%$ & 28 & $90,3 \%$ \\
\hline & They don't unders & 0 & $0,0 \%$ & $13,8 \%$ & 3 & $9,7 \%$ \\
\hline & They don't have any interest & 0 & $0,0 \%$ & $13,8 \%$ & 0 & $0,0 \%$ \\
\hline
\end{tabular}

By comparing the responses in relation to their academic achievement, shown in Table 5, we noticed an even distribution when it comes to students with very good and excellent marks. Namely, $40,7 \%$ of pupils with very good and $51,1 \%$ with excellent school marks turn to teachers and class supervisors for help, and the same number of students think they themselves are involved in conflict resolution. These students also emphasize the engagement of their parents and their willingness to help them deal with conflicts.

Unlike students with better academic achievement, students who achieve good marks are generally not turning for help to anyone. They include peers in conflict resolution $(42.9 \%)$. Although most of the students with good marks replied that parents are engaged in helping them to resolve the conflict, a third of them $(28.6 \%)$ answered that parents have no understanding of the issues which are related to peer conflicts. With these students, there is a consciousness and tendency that conflicts should be concealed from

Table 5 Adults' assistance in conflict resolution in relation to their academic achievements

\begin{tabular}{|c|c|c|c|c|c|c|c|}
\hline \multirow{3}{*}{ Conflicts } & \multirow[b]{3}{*}{ Students' perception } & \multicolumn{6}{|c|}{ Academic achievements } \\
\hline & & \multicolumn{2}{|c|}{ Good } & \multirow{2}{*}{\multicolumn{2}{|c|}{$\begin{array}{c}\text { Very good } \\
\%\end{array}$}} & \multicolumn{2}{|c|}{ Excellent } \\
\hline & & $\mathrm{f}$ & $\%$ & & & $\mathrm{f}$ & $\%$ \\
\hline \multirow{4}{*}{$\begin{array}{l}\text { People who are } \\
\text { involved in } \\
\text { conflict } \\
\text { resolution }\end{array}$} & Other students & 3 & $42,9 \%$ & & $22,2 \%$ & 4 & $8,5 \%$ \\
\hline & Class supervisor & 2 & $28,6 \%$ & 1 & $40,7 \%$ & 24 & $51,1 \%$ \\
\hline & Teachers & 1 & $14,3 \%$ & 1 & $3,7 \%$ & 4 & $8,5 \%$ \\
\hline & Psychologist, pedagogue & 1 & $14,3 \%$ & 9 & $33,3 \%$ & 15 & $31,9 \%$ \\
\hline \multirow{5}{*}{$\begin{array}{l}\text { People whom } \\
\text { they turn to for } \\
\text { help }\end{array}$} & Friends & 1 & $14,3 \%$ & 5 & $18,5 \%$ & 3 & $6,4 \%$ \\
\hline & Teachers, the class supervisor & 1 & $14,3 \%$ & 11 & $40,7 \%$ & 24 & $51,1 \%$ \\
\hline & Psychologist, pedagogue & 1 & $14,3 \%$ & 5 & $18,5 \%$ & 9 & $19,1 \%$ \\
\hline & Parents & 1 & $14,3 \%$ & 3 & $11,1 \%$ & 6 & $12,8 \%$ \\
\hline & No-one & 3 & $42,9 \%$ & 3 & $11,1 \%$ & 5 & $10,6 \%$ \\
\hline \multirow{3}{*}{$\begin{array}{l}\text { Parents' } \\
\text { willingness to } \\
\text { assist }\end{array}$} & Fully willing to help & 5 & $71,4 \%$ & 25 & $92,6 \%$ & 46 & $97,9 \%$ \\
\hline & They don't understand my problems & 2 & $28,6 \%$ & 2 & $7,4 \%$ & 0 & $0,0 \%$ \\
\hline & They don't have any interest & 0 & $0,0 \%$ & 0 & $0,0 \%$ & 1 & $2,1 \%$ \\
\hline
\end{tabular}


adults and that it is a "normal" phenomenon (Jevtić \& Ivanović, 2014). Based on the results, we can assume that distrust and negation of the importance of an adult's roles related to pupils' achievements in the educational and social context.

By calculating $\chi^{2}=11.755$ at the degrees of freedom $\mathrm{df}=4$ where the level of significance is $\mathrm{p}=0,019$, we concluded that there is a statistically significant difference in the students' perception on getting assistance from adults in conflict resolution, which confirms the second research hypothesis.

\section{CONCLUSION}

The school as a social institution has the most opportunities to plan, organize and systematically influence the students' education and upbringing and, in that sense, has a certain responsibility to prevent and reduce conflicts among pupils. When students feel safe and good, it contributes to the orientation towards socially acceptable forms of behavior, feelings of affection, adaptation, as well as reducing negative feelings and misconduct.

In investigating the perception of primary school pupils towards conflict, we started from the assumption that there are statistically significant differences in the perception of the school conflict frequency, and that there are statistically significant differences in students' view on getting assistance from adults in conflict resolution. The results of the study showed that there are conflicts present in the school that had been a sample for this research, but that their frequency differs from the grade. Also, the number of conflicts increases with age, but the number of different participants in conflicts is decreasing, which shows the tendency that usually the same students partake in these conflicts.

We also wanted to find out if the conflict frequency differs in relation to students' academic achievement. We have come to the conclusion that participation in conflicts is particularly pronounced among students with lesser academic achievements.

By analyzing the structure of the people to whom children are turning for help, we have noticed that students are prone to talking to teachers and professional associates rather than parents. Although pupils prefer to turn to teachers for help, most of them have expressed confidence that their parents are willing to engage in conflict resolution among peers. Almost all parents are aware of how difficult it is to change educational models and patterns of behavior in the family and in parent-child relationships. The parents can formally (through the Parent's Council) and informally participate in the peer conflicts prevention and resolution, first of all by engaging personally, in a suitable manner.

To a community that, in the name of a healthy future, recognizes the importance of good children upbringing, it is important to have good educational institutions that offer values, skills, and knowledge necessary to lead a quality life. If our society wants to have children / young people who are responsible and self-disciplined and who show a high level of personal responsibility and social awareness, it is important to develop values at all levels of society that contribute to the creation of a supportive and motivating environment for every child in the community. 


\section{REFERENCES}

Deutsch, M., Coleman P. T., \& Marcus, E. C. (eds.) (2006). The Handbook of Conflict Resolution: Theory and Practice. San Francisco: Jossey-Bass Publishers.

Jevtić, B., \& Ivanović, M. (2014). Nasilje u lavirintu globalizacije [Violence in the labyrinth of globalization]. U: Dimitrijević, B. (ur.): Tematski zbornik radova Savremene paradigme u nauci i naučnoj fantastici (370384) [Proceedings of papers Contemporary paradigms in science and science fiction]. Niš: Faculty of Philosophy.

Jevtić, B. (2015). Retro(per)spektiva (a)socijalizacije [Retro (per) spectrum (s) of socialization]. Niš: Filozofski fakultet.

Jovanović, M. (2009). Efikasnom pedagoškom komunikacijom protiv nasilja u školi [Effective pedagogical communication against violence at school]. U: Milosavljević, Lj. i sar. (prir.). Protivurečnosti socijalizacije mladih i uloga obrazovanja u afirmaciji vrednosti kulture mira (str. 273-283) [The contradictions of the socialization of young people and the role of education in the affirmation of the values of the culture of peace]. Niš: Filozofski fakultet.

Johnson, D. W, \& Johnson, R. T. (1996). Conflict Resolution and Peer Mediation Programs in Elementary and Secondary Schools: A Review of the Research. Review of Educational Research, 66, 4, 459-506.

Jones, T. S. (2004). Conflict resolution education: The field, the findings, and the future. Conflict Resolution Quarterly, 22(1-2), 233-267.

Mirolović Vlah, N. (2004). Neki aspekti socijalnih sukoba [Some aspects of the social conflict]. Napredak [Progress], 146, 2, 220-229.

Petrović, S. D., \& Vučetić, M. (2012). Vrsta konflikata, tip odnosa i preferirane strategije [Type of conflict, type of relationship and preferred strategy]. Zbornik instituta za pedagoška istraživanja [Journal of the Institute for Educational Research], 1, 163-178.

Popadić, D. (2009). Nasilje u školama [Violence in Schools]. Beograd: Institut za psihologiju.

Rot, N. (2010). Psihologija grupe [Psychology of the group]. Beograd: Zavod za udžbenike i nastavna sredstva.

Suzić, N. (2010). Akademski self koncept i vršnjačko nasilje [Academic self-concept and peer violence]. Banja Luka: Filozofski fakultet. Retrieved from http://suzicnenad.com/wp-content/uploads/2015/05/Akademskiself-koncept-i-vrsnjacko-nasilje.pdf

Zdravković, D. (2010). Global education: education for piece and less violence. Didactika Slovenica, 170-184.

Zečević, I. (2010). Program prevencije vršnjačkog nasilja u školama [Program of prevention of peer violence in schools]. Banja Luka.

Tomonjić, G., Blagojević-Radovanović, R., \& Pavlović, J. (2010). Koliko je nasilje prisutno u školi [How much violence is present at school]. Pedagoška stvarnost [Pedagogical Reality], 1-2, 46-58.

Vlah, N. (2010). Pojam i struktura socijalnog sukoba The concept and structure of the social conflict], Odgojne znanosti [Educational Sciences], 2, 373-384.

***(2009): Priručnik za primenu posebnog protokola za zaštitu dece $i$ učenika od nasilja, zlostavljanja $i$ zanemarivanja u obrazovno-vaspitnim ustanovama [A Handbook for the Implementation of a Special Protocol for the Protection of Children and Students against Violence, Abuse, and Neglect in Educational Institutions]. Beograd: Ministarstvo prosvete Republike Srbije. Retrieved from https://www.unicef.org/serbia/PRIRUCNIK_ 1.04.pdf 


\section{SUKOBI U OSNOVNOJ ŠKOLI KROZ PERCEPCIJU UČENIKA}

Odrastanje svakog deteta prate sukobi - u školi, porodici, među drugovima, u sportskim klubovima. Danas deca žive u vreme čestih manifestacija vršnjačkog nasilja, bilo da je ono verbalno, psihičko ili fizičko. Često se u pokušajima rešavanja sukoba dođe u situaciju da se sukob još više produbi. Uzrok tome je različit ugao sagledavanja problema. Cilj ovog istraživanja je učenička percepcija sukoba u osnovnoj školi. $U$ radu su korišćene metoda deskriptivne statitike (frekvencija) $i \chi^{2}$ test za merenje značajnosti razlika među segmentima ukrštenih varijabli. Rezultati istraživanja su pokazali da se broj sukoba povećava sa uzrastom, $t$. da je u starijim razredima više sukoba nego u mlađim. U rešavanju sukoba, učenici se radije obraćaju nastavnicima i stručnim saradnicima u školi i pored toga što njihovi roditelji pokazuju spremnost da se angažuju u rešavanju vršnjačkih sukoba.

Ključne reči: socijalni sukob, percepcija učenika, nasilno ponašanje, školska sredina, vaspitanje 